\title{
Barcode DNA Tanaman Leilem (Clerodendrum minahassae L.) Berdasarkan Gen matK
}

\author{
Cindy Kalangia, Vanda S. Kamua, Maureen Kumaunanga*
}

aJurusan Kimia, FMIPA, Unsrat, Manado

$$
\text { KATA KUNC I }
$$

Tanaman Leilem

matk

Barcode DNA

\begin{abstract}
A B S T R A K
Gen matK merupakan gen pengkode protein maturasek yang terdapat pada kloroplas tumbuhan. Penelitian ini bertujuan untuk menentukan urutan nukleotida dari barcode DNA tanaman leilem (Clerodendrum minahassae L.) berdasarkan gen matK. Prosedur penelitian yang dilakukan meliputi: isolasi DNA total tanaman leilem, amplifikasi gen matK melalui PCR, sekuensing hasil PCR, serta penentuan barcode DNA leilem. Isolasi DNA total dari tanaman leilem telah dilakukan berdasarkan prosedur manual dari InnuPrep Plant DNA Kit yang dimodifikasi dengan menghasilkan larutan berwarna hijau kekuningan yang menunjukkan adanya klorofil yang larut. Gen matK parsial telah diisolasi dengan metode Polymerase Chain Reaction (PCR) menggunakan Primer Forward matK-1RKIM-f dan Primer Reverse matK-3FKIM-r. Analisis urutan nukleotida matK menghasilkan fragmen berukuran $843 \mathrm{pb}$. Kedua urutan nukleotida matK dari sampel tanaman leilem yang berasal dari Kauditan dan Tomohon menunjukkan hasil barcode DNA yang sama.
\end{abstract}

A B S T R A C T

MaturaseK is a protein encoded by matK gene which is located in plant chloroplast. The aim of this research was to determine the DNA barcode of leilem plant (Clerodendrum minahassae L.) based on matK nucleotides sequence. This research was done by isolating total DNA of leilem, amplified matK gene by PCR, sequencing the PCR product, and determined the DNA barcode of leilem. Total DNA of leilem plant was isolated by using the modified procedure from InnuPrep Plant DNA Kit. The DNA isolation resulted a green-yellowish solution which shows dissolved chlorophyll. Partial matK gene was amplified using PCR method with matK1RKIM-f as forward primer and matK-3FKIM-r as reverse primer. Amplification by PCR resulted a 843 bp DNA fragment of matK. Both nucleotide sequences of matK from two samples of leilem plant taken from Kauditan and Tomohon showed the same DNA barcode.

TERSEDIA ONLINE

20 Oktober 2014

\section{Pendahuluan \\ Indonesia merupakan negara yang kaya dengan keanekaragaman hayati dengan jenis tumbuhan yang bervariasi dan memiliki peranan penting dalam perkembangan ilmu dan teknologi. Dalam bidang kimia, keanekaragaman hayati ini termasuk dalam sumber daya alam yang menghasilkan senyawa kimia yang tidak terbatas}

jenis dan jumlahnya. Khususnya di daerah Minahasa, jenis tanaman yang banyak tumbuh dan dimanfaatkan sebagai sumber makanan yaitu tanaman leilem (Clerodendrum minahassae L.). Tanaman leilem ini termasuk dalam genus Clerodendrum dan famili Verbenaceae (Wiart, 2002). Bagian tanaman leilem ini yaitu daun, biasanya dikonsumsi sebagai sayuran oleh masyarakat di Minahasa. Manfaat lain dari daun 
leilem ini yaitu sebagai obat tradisional untuk menyembuhkan beberapa penyakit, seperti sakit perut dan cacingan (Patel and Shrivastava, 2007). Tanaman leilem ini biasanya tumbuh di sekitar pekarangan rumah. Tanaman leilem juga dapat tumbuh di daerah yang berbeda ketinggiannya, misalnya di desa Kauditan yang ketinggiannya $0 \mathrm{~s} / \mathrm{d}$ $240 \mathrm{~m}$ di atas permukaan laut dan di Kota Tomohon yang ketinggiannya $700 \mathrm{~s} / \mathrm{d} 800 \mathrm{~m}$ di atas permukaan laut.

Identifikasi spesies tumbuhan awalnya menggunakan metode morfologi yang diidentifikasi dari bentuk fisiknya (bunga, daun, batang, cabang dan biji). Namun, dengan adanya perkembangan teknologi elektronika dan genetika saat ini telah dikembangkan suatu metode terbaru dalam identifikasi spesies tumbuhan dan hewan, yaitu teknologi DNA barcoding yang menggunakan potongan DNA pendek standar (barcode DNA) (Herbert et al., 2003). Untuk identifikasi tanaman dalam teknologi DNA barcoding, disepakati menggunakan gen pengkode standar yaitu gen ribulosa-1,5-bifosfat karboksilase ( $r b c L)$ dan gen maturaseK (matK) yang terdapat pada kloroplas (CBOL Plant Working Group, 2009). Gen matK lebih banyak digunakan dalam berbagai penelitian dibandingkan gen rbcL, karena tingkat keakuratannya yang lebih spesifik pada yaitu pada tingkat spesies. Gen matK dijadikan gen pengkode standar untuk barcode DNA sejak tahun 2003 dan telah diuji melalui beberapa penelitian. Gen maturaseK (matK) diidentifikasi pertama kali oleh Sugita et al. (1985) dari tanaman tembakau (Nicotiana tabacum).Gen matK merupakan gen pengkode enzim maturase bagian sub-unit $K$ yang terdapat dalam kloroplas pada tanaman. Daerah urutan nukleotida gen matK ini dapat menghasilkan kira-kira 1500 pb (pasang basa) (Soltis et al., 1998).

Sampai saat ini belum ditemukan publikasi ilmiah mengenai identitas barcode DNA tanaman leilem (C. minahassae L.), yang telah tersimpan dalam BOLD (Barcode of Life Database) Systems (www.boldsystems.org). Oleh karena itu, perlu dilakukan penelitian mengenai sekuens barcode DNA tanaman leilem sebagai data inventaris identitas molekuler tanaman asli daerah Minahasa.

\section{Metode}

\subsection{Material}

Alat yang digunakan dalam penelitian ini adalah alat-alat gelas, hot plate, tabung Eppendorf $1,5 \mathrm{~mL}$, tabung PCR $50 \mu \mathrm{L}$, mikropipet, termoblok (Biometra), mikrosentrifugasi, alat PCR (Biometra Tpersonal, Jerman), elektroforesis, UVTransiluminator dan lemari pembeku.

Bahan yang digunakan dalam penelitian ini adalah daun leilem yang diperoleh dari desa Kauditan Kabupaten Minahasa Utara (CKK) dan Kota Tomohon (CKT). Kit untuk isolasi DNA tanaman menggunakan InnuPREP Plant DNA kit (Analytik Jena), primer forward matK-1RKIM-f dan primer reverse matK-3FKIM-r (Integrated DNA Technology (IDT), Singapura), master mix untuk PCR GoTaq ${ }^{\circledR}$ Green Master Mix (Promega), agarosa (Merck), akuades, etidium bromida (Merck) dan bufer Trisborat-EDTA (TBE, Promega).

\subsection{Isolasi DNA Total Tanaman Leilem}

Isolasi DNA total tanaman leilem dilakukan berdasarkan prosedur manual dari InnuPrep Plant DNA Kit yang dimodifikasi. Sampel dalam bentuk lembaran daun tanaman leilem berukuran $5 \times 5 \mathrm{~mm}$ dalam tabung Eppendorf ditambahkan Iarutan lisis sebanyak $300 \mu \mathrm{L}$ dan proteinase $\mathrm{K}$ sebanyak $25 \mu \mathrm{L}$ dengan menggunakan mikropipet dan diinversikan beberapa kali agar homogen. Setelah itu, diinkubasi selama 45 menit pada suhu $55^{\circ} \mathrm{C}$ menggunakan termoblok sambil diinversikan setiap 10 menit. Selanjutnya sampel dimasukkan ke dalam prefilter untuk difiltrasi dan disentrifugasi $12.000 \mathrm{rpm}$ selama 1 menit filtrat yang diperoleh ditambahkan dengan larutan pengikat sebanyak $200 \mu \mathrm{L}$ dan disentrifugasi $12.000 \mathrm{rpm}$ selama 1 menit. Filtrat dibuang, dan dimasukkan ke dalam tabung receiver dan ditambahkan dengan larutan pencuci HS sebanyak $500 \mu \mathrm{L}$ dan disentrifugasi $12.000 \mathrm{rpm}$ selama 1 menit dan difiltrasi kembali menggunakan spin filter. Setelah itu, ditambahkan larutan pencuci MS sebanyak $750 \mu \mathrm{L}$ dan disentrifugasi 12.000 rpm selama 1 menit. Selanjutnya, filtrat dibuang dan spin filter dimasukkan kembali ke dalam tabung receiver dan disentrifugasi $12.000 \mathrm{rpm}$ selama 1 menit. Kemudian spin filter dipindahkan ke dalam tabung Eppendorf baru dan ditambahkan dengan bufer elusi sebanyak $100 \mu \mathrm{L}$ dan didiamkan selama 1 menit pada suhu ruang. Selanjutnya disentrifugasi $10.000 \mathrm{rpm}$ selama 1 menit. Sampel isolat DNA disimpan pada $-20^{\circ} \mathrm{C}$

\subsection{Polymerase Chain Reaction (PCR) dan Penentuan Urutan Nukleotida matK}

Isolasi gen matK dilakukan dengan cara amplifikasi atau perbanyakan gen menggunakan PCR berdasarkan prosedur Kolondam et al. (2013) yang dimodifikasi. Reaksi PCR dalam penelitian ini menggunakan GoTaq ${ }^{\circledR}$ Green Master Mix (Promega). Komposisi PCR (volume total $40 \mu \mathrm{L}$ ), yaitu 1,25 Unit Taq DNA polimerase, 0,2 mM masing-masing dNTPs, 1,5 $\mathrm{mM} \mathrm{MgCl}$; 0,2 mM masing-masing primer dan kira-kira 0,6 $\mu \mathrm{g}$ DNA total sampel. Primer yang digunakan, adalah primer forward matK-1RKIM-f (5'-ACCCAGTCCATCTGGAAATCTTGGTTC-3') dan primer reverse matK-3FKIM-r (5'-CGTACAGTACTTTTGTGTTT ACGAG-3').

Kondisi reaksi PCR adalah: denaturasi awal pada $95^{\circ} \mathrm{C}$ selama 2 menit kemudian dilanjutkan 35 siklus [denaturasi: $95{ }^{\circ} \mathrm{C}, 30$ detik; penempelan primer: $50{ }^{\circ} \mathrm{C}, 30$ detik; dan pemanjangan DNA: $72^{\circ} \mathrm{C}, 50$ detik]. Pita DNA hasil PCR selanjutnya dielektroforesis menggunakan gel agarosa $1 \%$ dan divisualisasi menggunakan UV-Transiluminator. Produk PCR selanjutnya disekuensing di First Base Laboratories Sdn Bhd, Malaysia. 


\subsection{Analisis Barcode DNA}

Kromatogram DNA hasil sekuensing disunting menggunakan perangkat lunak Geneious v5.6 (Drummond et al., 2012). Bagian awal dan akhir hasil kromatogram DNA tersebut dihapus kira-kira $30 \mathrm{pb}$ (pasang basa) dan untuk pembacaan nukleotida yang keliru diperbaiki berdasarkan tingkat keakuratan yang terbaca. Untuk keakuratan amplifikasi gen target yang diuji menggunakan gen matK, dilakukan identifikasi melalui BOLD (Barcode of Life Database) Systems (www.boldsystems.org) (Ratnasingham and Hebert, 2007).

\section{Hasil dan Pembahasan}

\subsection{Hasil Isolasi DNA Total Tanaman Leilem}

Isolasi DNA total tanaman leilem dilakukan untuk mengamplifikasi gen target matK yang terdapat dalam kloroplas. Hasil isolasi DNA total untuk kedua sampel yang berasal dari Kauditan (CKK) dan Tomohon (CKT) berupa larutan jernih berwarna hijau kekuningan yang menunjukkan adanya klorofil pada daun leilem yang larut dalam larutan bufer yang digunakan selama proses isolasi. Hal ini disebabkan karena DNA target yang digunakan terdapat dalam kloroplas.

Produk PCR amplifikasi gen matK menghasilkan fragmen DNA seperti yang ditunjukkan dengan elektroforegram (Gambar 1). Pita DNA yang teramplifikasi yaitu 864 pb (sampel CKK) dan 856 pb (sampel CKT) untuk primer forward, sedangkan untuk primer reverse yaitu 867 pb (sampel CKK) dan 866 pb (sampel CKT).

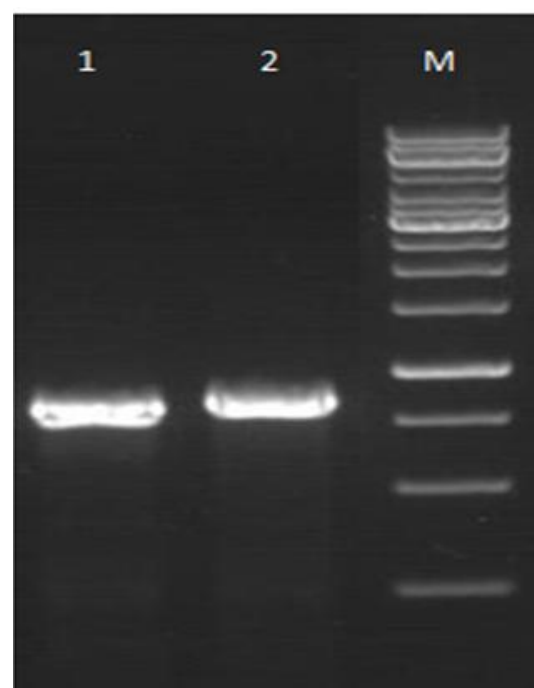

Gambar 1. Elektroforegram hasil PCR (M: marker DNA ladder $1 \mathrm{~kb}, 1$ : sampel CKT, 2: sampel CKK)

\subsection{Hasil Isolasi DNA Total Tanaman Leilem}

Hasil sekuensing dari produk PCR gen matK menghasilkan kromatogram yang berkualitas tinggi, yang ditunjukkan dengan nilai High Quality (HQ\%) kromatogram yang terbaca pada Geneious v5.6 yaitu $>90 \%$. Pita DNA teramplifikasi telah dihapus $33 \mathrm{pb}$ untuk bagian awal (primer forward matK1RKIM-f) dan 26 pb untuk bagian akhir (primer reverse matK-3FKIM-r), sehingga ukuran pita DNA menjadi $843 \mathrm{pb}$. Sebagian kromatogram hasil sekuensing diperlihatkan dalam Gambar 2.

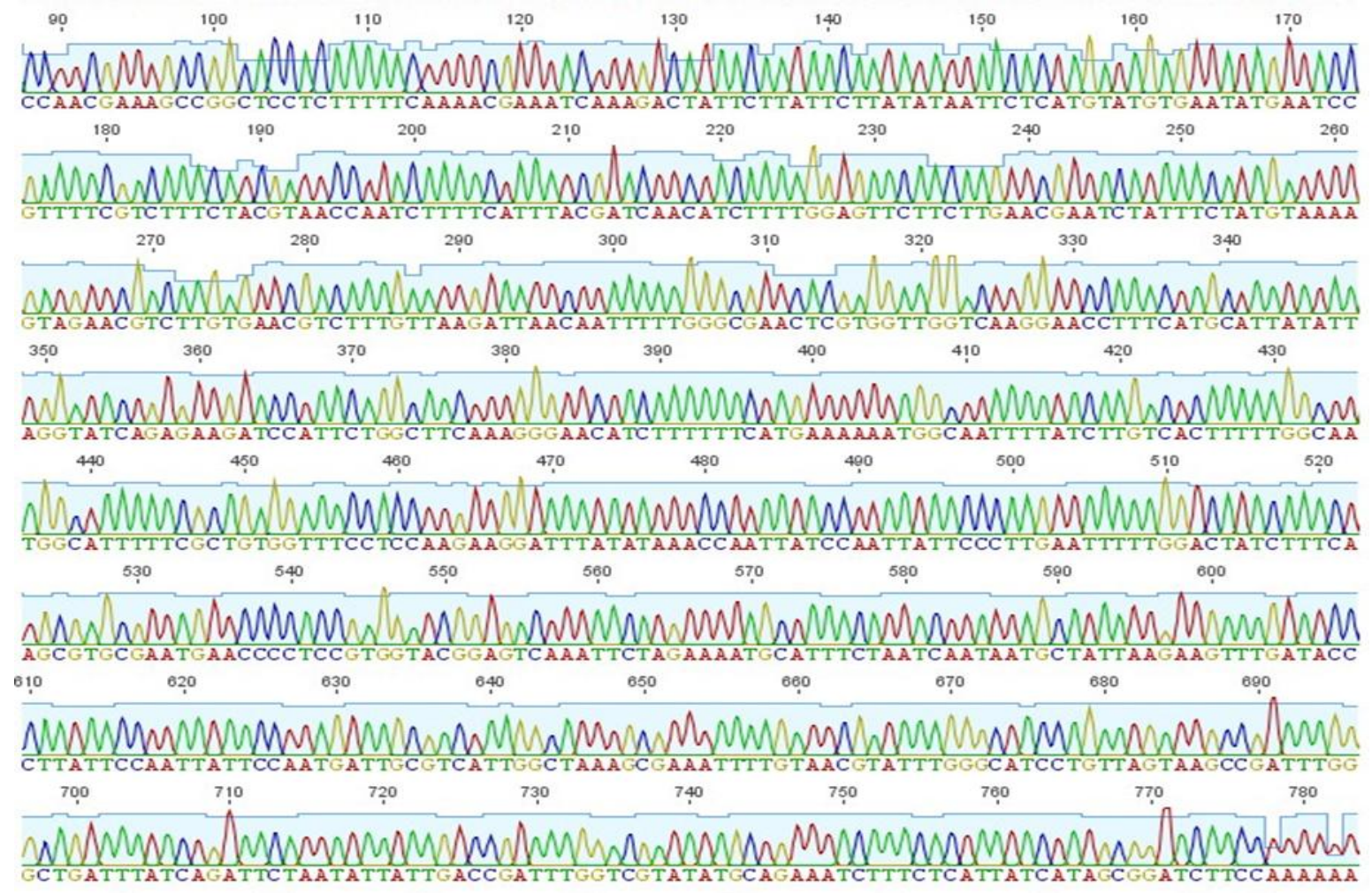

Gambar 2. Sebagian kromatogram hasil sekuensing sampel leilem (CKK) 
Barcode tanaman leilem diperlihatkan dalam Gambar 3. Penentuan barcode tanaman leilem diperkuat dengan penerjemahan nukleotida yang teramplifikasi menggunakan frame 3 (dibaca mulai dari nukleotida urutan ketiga) dalam program Geneious v5.6 (Drummond et al., 2012). Apabila menggunakan frame 1 dan 2 (dibaca mulai dari nukleotida urutan pertama dan kedua) akan menunjukkan adanya kodon stop di tengah urutan nukleotida. Gen matk merupakan gen aktif, sehingga tidak mungkin ada kodon stop yang terbentuk ditengah sekuens (Jing et al., 2011).

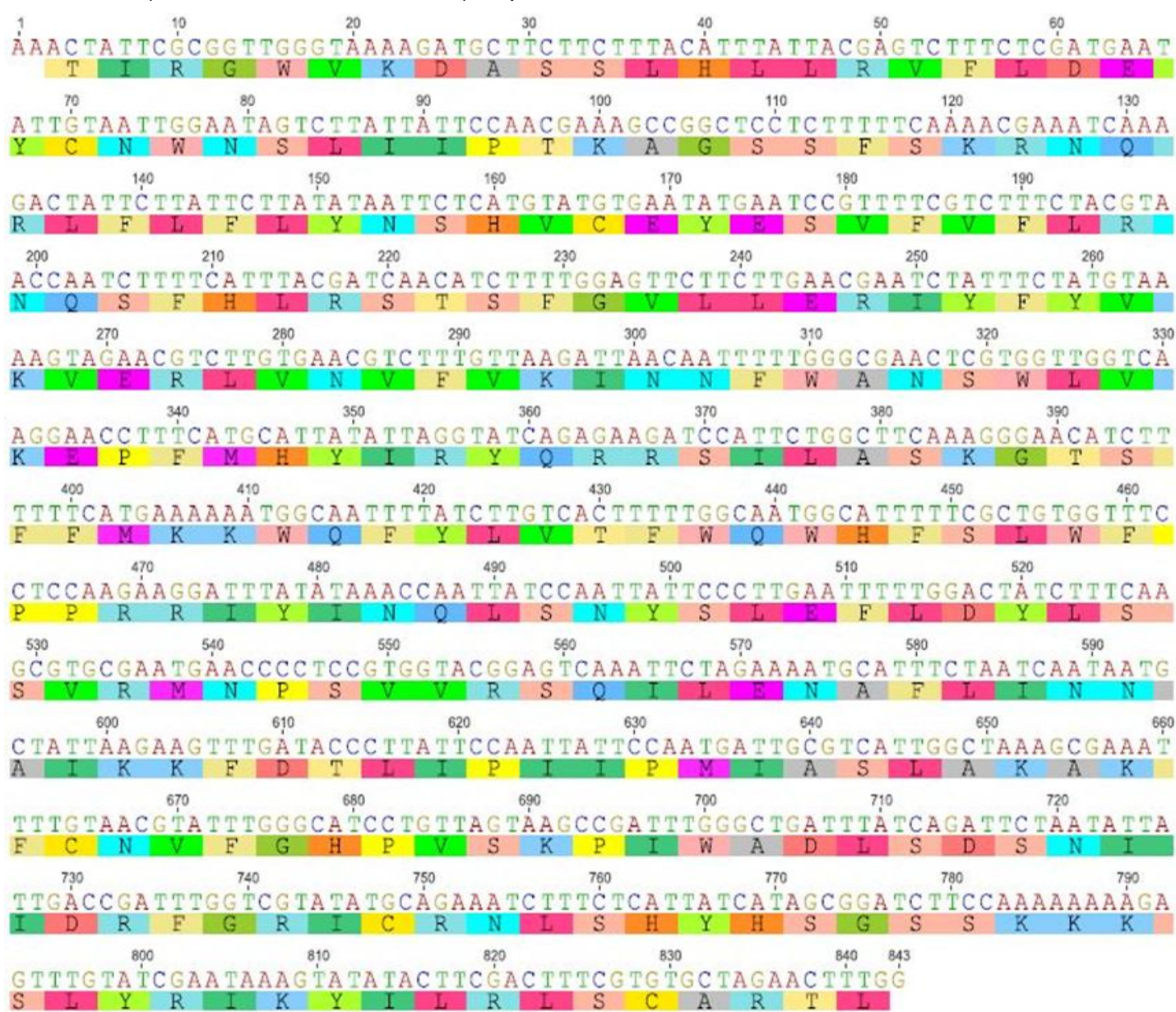

Gambar 2. Urutan Nukleotida Barcode DNA matK dan Asam Amino Tanaman Leilem. Baris bagian atas menunjukkan urutan nukleotida dan baris bagian bawah menunjukkan urutan asam amino.

Hasil identifikasi melalui BOLD (Barcode of Life Database) Systems (www.boldsystems.org) menunjukkan bahwa sampel tanaman leilem termasuk dalam genus Clerodendrum, karena urutan nukleotidanya mirip dengan genus Clerodendrum yang lain dengan tingkat kemiripan > 98\% (data tidak ditampilkan). Berdasarkan hasil penelusuran dalam data BOLD System, belum ditemukan barcode DNA untuk tanaman leilem ( $C$. minahassae L.).

\section{Kesimpulan}

Hasil isolasi DNA total kedua tanaman leilem yang berasal dari dua lokasi berbeda ketinggian, yaitu Tomohon dan Kauditan, berupa larutan jernih berwarna hijau kekuningan, serta pita DNA teramplifikasi yang terbaca yaitu 843 pb (pasang basa). Selain itu, kedua tanaman leilem adalah spesies yang sama, yaitu Clerodendrum minahassae
L., ditunjukkan dengan kesamaan barcode DNA keduanya berdasarkan urutan nukleotida gen matK.

\section{Daftar Pustaka}

CBOL (Consortium for the Barcode of Life) Plant Working Group. 2009. A DNA Barcode for Land Plant. Proceeding of the National Academy of Sciences. 106: 12794-12797.

Drummond, A. J., B. Ashton, S. Buxton, M. Cheung, A. Cooper, M. Kearse, S. Markowitz, S. Sturrock, T. Thierer, and A. Wilson. 2012. Geneious v5.6. Biomatters, New Zeland.

Hebert, P. D. N., N. A. Cywinska, S. L. Ball, and J. R. de Waard. 2003. Biological Identifications Through DNA Barcodes. Proceedings of the Royal Society B: Biological Science. 270: 313-321.

Jing, Y., X. Jian-Hua, and Z. Shi-Liang. 2011. New Universal matK Primers for DNA Barcoding Angiosperms. Journal of Systematics and Evolution. 49: 176-181. 
Kolondam, B. J., E. Lengkong, J. Mandang, S. Runtunuwu, dan A. Pinaria. 2013. Barcode DNA Anthurium Gelombang Cinta (Anthurium plowmanii) Berdasarkan Gen rbcL dan matK. Jurnal Bioslogos. 3:17-25.

Kress, W. J., K. J. Wurdack, E. A. Zimmer, L. A. Weigt, and D. H. Janzen. 2005. Use of DNA Barcodes to Identify Flowering Plants. Proceeding of the National Academy of Sciences. 102: 8369-8374.

Patel,T. and N. Shrivastava. 2007. Clerodendrum and Heathcare. Medicinal and Aromatic Plant Science and Biotechnology. 1: 142-150.
Ratnasingham, S. and P. D. N. Hebert. 2007. BOLD: The Barcode of Life Data System. Molecular Ecology Notes. 7: 355-364.

Soltis, P. S., D. E. Soltis, and J. J. Doyle. 1998. Molecular Systematics of Plants. International Thomson Publishing, New York.

Sugita, M., K. Shinozaki, and M. Sugiura. 1985. Tobacco Chloroplast tRNALys(UUU) Gene Contains a 2,5-kilobase-pair Intron. Proceeding of the National Academy of Sciences. 82: 35573561.

Wiart, C. 2002. Medicinal Plants of Southeast Asia. Prentice Hall, Malaysia. 